\title{
KONFIGURASI DAN TRANSFORMASI KEHIDUPAN AGAMA MENJELANG TINGGAL LANDAS PEMBANGUNAN NASIONAL DI KECAMATAN LAMBUYA KABUPATEN KENDARI PROPINSI SULAWESI TENGGARA
}

\author{
Oleh : Drs. Pat. Badrun. MS
}

\section{PENDAHULUAN}

\section{Masalah Penelitian dan Cakupannya}

Kehadiran Departcmen Agama di dalam siruktur Pemcrintah Negara Kesatuan Rcpublik Indonesia Sejak awal tcrbentuknya negara ini,dapatdiartikanbahwa pembinaan dan pclayanan pemcrintah di bidang kehidupan bcragama warga negara mendapat perhatian yang sama dengan bidang kehidupan lainnya. Melalui instansi ini dengan jajaran serta cabang-cabang vertikalnya di daerah-daerah, diletakkan dasar-dasar serta dikembangkan upaya pembinaan dengan penyediaan Prasarana, sarana danperangkat konseptual pelayanan dan bimbingan agama bagi masyarakat pemcluk agama.

Dalam k ai tanny a dengan tahapan pern bangunan dewasaini pertanyaan pokok yang mendesak dicarikan jawaban ialah apakah upaya yang telah dilakukan itu sudah mampu menyangga kebutuhan tinggal landas pembangunan pada PELITA VI yang akan datang?

Dalam upaya memperoleh Jawaban pertanyaan di atas maka dalam dua tahun anggaran terakhir, Badan Litbang Agama melaksanakan penelitian lapangan dengan topik "Konfigurasi dan Transformasi Kehidupan Agama Menjelang Tinggal Landas Pembangunan Nasional."
Dal am pencliti an ini, pertanyaan pokok di atas, dijabarkan secara opcrasional menjadi lima masalah, yakni:

1. Seperti apakah aparat Dep. Agama yang ada dibagian paling bawah (antara lain KUA Kecamatan) memberikan pelayanan dan bimbingan agama, serta seperti apakah corak pelayanan dan bimbingan yang diberikan itu?

2. Bagaimana institusi-institusi agama (nilai, lembaga, organisasi, kepemimpinan) telah berubah dewasa ini sebagai dampak pembangunan nasional atau modcrnisasi?

3. Bagaimana pola-pola akulturasi dan inkulturasi agama melalui pendidikan formal ataupun pendidikan keluarga di kalangan masyarakat dewasa ini?

4. Bentuk-bentuk dan isi dakwah agama yang bagaimana yang berkembang dan dibutuhkan masyarakat dewasa ini.

5. Literatur-literatur agama apa yang masih dibaca dan dianggap perlu bagi masyarakat dewasa ini?

Kelimamasalah dijadikan acuan dalam rangka mencari pemahaman yang tepat tentang : (1) fungsi dan peranan Departemen Agama selama ini dalam kehidupan masyarakat, (2) bagaimana masyarakat agama telah berubah sehingga menuntut bentuk-bentuk pclayanan dan bimbingan keagamaan yang baru dalam situasi masyarakat agama yang berubah itu sebagai akibat 
modernisasi global dan pembangunan Indonesia, (3) bagaimana isi dan bentuk kelembagaan penerusan nilai dan norma agama dewasa ini, (4) Bagaimana pola kepemimpinan dan keumatan sekarang ini telah berubah di kalangan masyarakat, dan (5) dalam batas-batas mara fungsi agama dalam struktur kehidupan masih dapat dipertahankan.

\section{Penjelasan operasional tentang kon- sep Konfigurasi dan Transfonnasi kehidupan agama.}

Konsep konfigurasi dan transformasi di sini digunakan dalam kaitan kehidupan agama, dan dalam konteks penelitian ini. Secara kontekstual, pengertian kedua konsep telah dijelaskan di dalam disain penelitian yang dijadikan acuan umum penelitian ini. Karena itu penjelasan yang diberikan di sini adalah penjelasan yang bersifat operasional, yakni penjabaran dari batasan daiam disain menurut kescsuaiannya dengan kenyataan di lapangan.

Konfigurasi kehidupan beragama, sesuai batasan dalam disain penelitian. diartikan sebagai suatu gambaran yang menyeluruh tentang nilai, kaidah,pola-pola kelakuan dan tindakan para penganut suatu agama yang bcrkaitan dengan kcyakinan yang dimiliki olch masing-masing individu sebagai suatu komuniti kcagamaan (umat). Keyakinan yang dijadikan acuan dalam bertindak terscbut bcrsumber dari ajaran agama dan ada kalanya berkaitan dengan kebudayaan atau keyakinan lain yang telah dianggap sebagai kcyakinan scndiri dan dianggap tidak bertentangan dengan ajaran agama yang asli.

Transformasi kehidupan beragama, menurut pengertian dalam disain penclitian, adalah pcrubahan dalam pcnafsiran dan pengalaman ajaran agama. Pcrubahan ajaran agama pada dasarnya memang tidak akan pernah terjadi, tetapi penafsiran terhadap ajaran agama itu senantiasa berubah. Karena penafsiran agama berkembang dan berubah maka pengamalannya pun mengalami perubahan-perubahan.

Mcmperhatikan pengertian yang diberikan tcrhadap kedua konsep tersebut di atas tampak bahwa konfigurasi dan transformasi kehidupan beragama lebih cenderung dilihat sebagai proses sosial budaya (sosiokultural); yakni gambaran tentang pola dan dinamika kehidupan beragama di suatu daerah/komunitas yang dipcngaruhiolchnilaibudayadandinamika sosial yang hidup dan berkembang di dalam masyarakat bersangkutan. Faktor penting lainnya yang dianggap mcmpengaruhi proses konfigurasi dan transformasi kehidupan agama di suatu daerah/komunitas di Indonesia ini ialah faktor bimbingan dan pelayanan kcagamaan, baik yang diiakukan olch instansi dan/atau aparat formal yang bcrwenang maupun yang dilakukan olch organisasi/lcmbaga dan/atau pemuka agama dalam komunitas bersangkutan. Karena itu, faktor-faktor tersebut diamati dengan seksama dalam penclitian ini.

\section{Metode/Cara kerja Penelitian}

Penclitian ini merupakan kumpulan studi kasus yang dilaksanakan olch sebuah tim bcranggotakan 5 (lima) orang dengan susunan sebagai bcrikut:
I.Pat. Badrun
: Ketua Tim/ Pencliti

2. Ahmad Rahman: Anggota/Pcneliti

3. H. Makkulawu : Anggota/Pencliti

4. Muhammad As'ad : Anggota/Pcneliti

5. H.M.Alwi Nawawi: Anggota/Pencliti

Penclitian lapangan dilaksanakan di Kecamatan Lambuya Kabupaten Kendari Propinsi Sulawesi Selatan dan empat desa 
sasaran (Sebuah kclurahan d a n 3 buah desa) di dalam wilayah Kecamatan Lambuya yakni, Kclurahan Lambuya, desa Matahoalu, desa Ucpay, dan desa Sonai. Pcmilihan wilayah kecamatan lokasi penelitian, sepenuhnya berdasarkan penunjukar Gubcrnur Kcpala DacrahTingkat I Propinsi Sulawesi Tenggara dengan mengindahkan pcrtimbangan dari Kcpala Kantor Wilayah Departcmen Agama setempat dan kritcria umum yang ditcntukan pimpinan proyck (scbagaimana dieantumkan di dalam Rcncana dan disain penelitian). Scdangkan penentuan desa lokasi sasaran penelitian dilakukan mclalui musyawarah antara tim pcncliti dengan Camat dan Kepala KUA Kecamatan Lambuya.

Pengumpulan data dan informasi di lapangan dilakukan dengan tiga cara pokok : (1) menyalin scmua data sukender yang berkaitan; (2) mclakukan pengamatan secara inlensif; dan (3) melakukan wawancara tcrbuka dan mendalam dengan masyarakat, pemuka masyarakal atau tokoh adat, pemuka agama, dan pcjabal formal yang dipandang pcrlu dan tcrkait. Khusus pe1 ak sanaan cara kcti ga tcrscbut di atas, dikem bangkan satu mctodc diskusi kelompok yang discbut "focused group discussion" (FGD) dalam mana pencliti memperolch banyak informasi yang memiliki tingkal akurasi yang cukup tinggi.

Scluruh data dan informasi yang dipcrolch mclalui tiga teknik pengumpulan data tcrscbut di atas dihimpun oleh masingmasing pcncliti di dalam semacam Catalan lapangan (Held notes) dan scbagian diantaranya (yakni informasi hasil wawancara) direkam dengan radio rckaman mini.

Data yang dikumpulkan oleh masingmasing anggota tim peneliti diolah dan dianalisa langsung kemudian disusun menjadi sebuah laporan tentang konligurasi dantransformasi kchidupanagamapada dcsa lokasi penelitian masing-masing. Laporan-laporan itu kemudian di edit dan dianlisis oleh ketua tim menjadi sebuah laporan bcrjangkau willayah kecamatan dengan judul lengkap: "Laporan Penelitian Konligurasi dan Transformasi Kehidupan Agama Mcnjclang Tinggal Landas Pembangunan Nasional di Kecamatan Lambuya Kabupalen Kendari Propinsi Sulawesi Tenggara."

Susunan laporan penelitian, baik laporan tingkal desa maupun laporan tingkat Kecamatan discsuaikan dengan ragangan (outline) yang iclahditcntukan dalam disain penelitian.

Kegiatan penelitian di lapangan secara resmi dimulai sctelah para pcncliti diterima resmi oleh pemimpin pemerintahan desa/ kclurahan tempat bertugas masing-masing sckaligus langsung menginap di lokasi lempat bertugas.

Sclama penelitian lapangan berlangsung para pcncliti mcnerapkan tiga macam tcknik/cara pengumpulan data lapangan sepcrti telah dikemukakan di atas. Dalam upaya mcnuntaskan perolehan suatu informasi atau rangkaian informasi, terkadang scorang peneliti mencari sumbcr informasi diluar desa lokasinya atau di ibukota kecamatan.

Sclama bcrlangsung penelitian lapangan, sckali scpekan ketua tim mcngunjungi desa/kelurahan lokasi penelitian untuk memantau kegiatan dan mcmeriksa catatan-catatan lapangan anggota tim sckaligus mendiskusikan hal-hal atau temuantcmuan yang dipandang menarik. Diskusi 
lengkap anggota tim dilakukan dua kali bertempat di ibukota kecamatan (tempat menginap ketua tim).

Ketua tim juga melakukan tiga macam kegiatan pengumpulan data dan/atau informasi yang berluang lingkup wilayah kecamatan lokasi penelitian.

Menjelang penelitian lapangan berakhir, dilakukan diskusi dengar pendapat di ibu kota Kecamatan Lambuya, dihadiri oleh 15 kepala desa (termasuk empat desa lokasi sasaran penelitian), Camat dan unsur Muspida setempat bahkan dihadiri pula oleh Bupati Kepala Daerah Kabupaten Kendari.

Sebelum meninggalkan lokasi penelitian, dilakukan kunjungan pamitan kepada Bupati Kepala Daerah dan Kepala Kantor Departemen Agama Kabupaten Kendari di Unaaha, Gubernur Kepala Daerah Tingkat I dan Kepala Kantor Wilayah Departemen Agama Propinsi Sulawesi Tenggara di Kendari, setelah lebih dahulu berpamitan dengan Camat dan Kepala KUA Kecamatan Lambuya.

\section{GAMBARAN UMUM WILAYAH KECAMATAN LAMBUYA}

\section{Setting Lokasi Penelitian}

Kecamatan Lambuya adalah salah satu dari 21 kecamatan yang terdapat dalam wilayah Kabupaten Kendari Propinsi Sulawesi Tenggara. Bagian terbesar dari wilayahnya membentang menyusur jalan raya Propinsi yang menghubungkan Kota Kendari di pantai Laut Banda dengan kota Kolaka di pantai Teluk Bone.

Secara astronomi, wilayah Kecamatan Lambuya berada di antara $3^{\circ}$ sampai $4^{\circ} 25^{\prime}$ Lintang Selatan dan diantara $121^{\circ} 37^{\prime}$ sampai $123^{\circ} 15^{\prime}$ Bujur Timur. Luas seluruh wilayahnya $1.408,83$ kilometer persegi (Km2), berbatasan dengan Kecamatan Unaaha di sebelah Utara, Kecamatan Tinanggea di sebelah Selatan, Kecamatan Landono di sebelah Timur, dan Kecamatan Tirawuta (Kabupaten Kolaka) di sebelah Barat.

Pada bagian timur wilayah Kecamatan Lambuya, kcadaan geografisnya berbukitbukit, sebagian besarditumbuhi hutan lebat seluas 56.606 hektar, hutan sejenis seluas 1.577 hektar, dan belukar seluas 53.937 hektar. Semakdan rawa-rawa sebagian besar terdapat di bagian tengah membujur dari Barat ke Timur dengan luas 23.884 hektar; bagian tengah dari rawa itu dikenal masyarakat setempat dengan nama Rana Aopa yang banyak menghasilkan ikan air tawar.

Wilayah Kecamatan Lambuya memiliki potensi sumber daya alam yang prospektif untuk pemenuhan kebutuhan kesejahteraan hidup penduduk setempat. Lahan persawahan seluas 8.653,5 hektar, lokasi pemukiman seluas 1.826,5 hektar, tanah kering, belukar dan rawa yang juga potensial seluas $77.695,98$ hektar.

Perkampungan penduduk sebagian besar berada di pinggir jalan, baik jalan raya poros Kendari-Kolaka maupun jalanjalan desa danjalan penghubung antar desa, dengan menempati areal seluas 1.536 hektar. Di sekitar perkampungan penduduk membentang lahan persawahan seluas 8.653 hektar, tegaan seluas 1.941 hektar, dan lahan perkebunan seluas 1.070 hektar.

Ibukota Kecamatan Lambuya terletak di Kelurahan Lambuya, berjarak 82 kilometer dari kota Kendari ibukota Propinsi Sulawesi Tenggara, 12 kilometer dari kota Unaaha ibukota Kabupaten Kendari 


\section{Administrasi Pemerintahan.}

Kecamatan Lambuya dibentuk pada tahun 1963, wilayahnya meliputi bekas wilayah Distrik Lambuya, kelika barudibentuk wilayahnya melipuli 11 desa gabungan.

Kini wilayah kecamatan Lambuya terdiri atas 28 desa definitif, satu kelurahan, dan dua unit pemukiman transmigrasi (UP). Jadi jumlah scluruhnya 31 desa atau sctaraf desa, masing-masing: (1) Kelurahan Lambuya, (2) Dcsa Ucpay, dan desa desa (3) Kemeroro, (4) Rawua, (5) Tanggobu, (6) Oncmbute, (7) Puriala, (8) Mokalcleo, (9) Aopa,(10)Motaha, (l 1) Angata, (12) Lamara, (13) bemua, (14) Puao, (15) Tateasa, (16) Lamoiso, (17) Matahoaiu. (18) Tawamelewc, (19) Kasebo, (20) Tawarotcbota, (21) Horodopi, (22) Pudcmbu, (23) Landabaru, (24) Sonay, (25) Awuliti, (26) Pumggawukawu, (27) Poanaha, (28) Basalc, (29) Trimulya, (30) UPT Ulu Meraka, (31) UPT Sandasi Jaya.

CAnat Lambuya berasama stafnya bcrkantor pda sebuah kantor permancn, tcrletak di pinggir jalan raa propinsi, di tcngah-tcngah pusat kcgiatan masyarakat ibukota kecamatan, seperti pasar, lapangan olah raga, masjid, gcrcja, sckolah (sd dan smp), panti asuhan harapan mulia (milik protestan), dan kantor-kantor instansi lainnya.

Dikantor Camat, turut pula (menumpang)bcrkantoraparat/pcjabatdari

11 instansi ,baik unsur departemen dalam negegeri linnya maupun instansi vcrtikal lainnya scperti(1) Pckcrjaan umum, (2) Pcrianian, (5) Pcrkebunan. (6)Perikanan, (7) Pcternakan, (8) Kehutanan, (9) BKKBN, (10) Petugas Departemen Sosial, dan (11)Juru Pcncrangan (Departemen Pencrangan)
Instansi vertikal tingkat kecamatan yang mcmpunyai perkantoran sendiri ialah (1) KUA Kecamatan Lambuya, (2) Kantor Depdikbud KEcamatan Lambuya, (3) Koramil, (4) Polsek, (5) PUSKESMAS, (6) Pos dan Giro, (7) Pengairan, (8) Balai Bcnih Padi, dan Unit-unit operasional Instansi lainnya, masing-masing bcrdomisili didesa lempat pusat kegiatannya.

Dari 31 desa/sctingkat dalam wilayah kecamatan Lambuya, semuatelahmemiliki Balai Dcsa, namun hanya 10 desa yang mcmiliki kantor dsa (lermasuk kelurahan Lambuya). Dari29 dcsa defenitif, 19dcsa diantaranya sudah mencapai kualifikasidesa swasmbada dan 10 dsa lainnya masih bcrkualinkasi desa swakarya.

Sclain Camat sclaku Kepala wilayah Pemerintahan, administrasi pemerintah dikclola olch 24 oramg Pegawai Staf terjabarkan kc dalam unit-unit kcrja yang ada sesuai dengan struktur organisasimya. dengan tingkatn kepangkatan / golongan gaji :3 oranggolngan $\mathrm{Hi}, 18$ oranggolongan II, dan 3 orang golongan I. Camalnya bcrnamaDrs. BasulaTamburake alumni Fakultas Sospol UNHAS, golomgam III/B.

Wilayah administasi pemerintahan desa (31 unil)dijabarkanlebihlanjutmenjadi III dusun/ kampung 156 Rukun Warga (RW), dan 325 rukun Tctangga (RT). Pada setiap desa telah diangkat Pcmbantu PPN yang sebagian besar diambil dari Imam Desa setcmpat.

\section{Kependudukan dan Mata Penca-} harian.

Penduduk Kccalatan Lambuya menurut data terakhir tahun 1990, berjumlah 34.316 jiwa, tcrsiri dari 17.511 jiwa lakilaki dan 6.711 bcrarti keadalan penduduk 
rata-rata 24 orang setiap kilo meter persegi.

Kepadatan penduduk dilihat per desa, sangat bervariasi. Yang paling rendah ratarata 8 atau 9 orang setiap kilometer persegi (desa Landabaro dan Lamoso), sedangkan yang paling padat rata-rata 145 jiwa setiap kilometer persegi (Desa bekas UPT Trimulya).

Komposisi usia penduduk mcnunjukkan bahwa usia antara 0 sampai 14 tahun bcrjumlah 15.326 jiwa atau mencapai $45 \%$ dari jumlah seluruh penduduk kecamatan Lambuya. Usia 55 tahun keatas bcrjumlah 1.704 jiwa atau 5\% dari jmlah seluruh penduduk.Hal ini berarti bahwa jmlah pendduk yang berusia kurang produktii" (usia 0-14 tahun dan 55 tahun kc atas dibandingjumlah penduduk yang berusia produktii' yaitu 15-54 tahun).

Pendudk Kecamatan Lambuya sccara umum terdiri dari dua golongan besar yakni penduduk asli dan penduduk pendatang. Penduduk asli dikcnal dengan sebutan Toalki, mendiami seluruh wikayah bekas daerah kerajaan Konae dan Mekongga yang kini masing-masing mcrupakam wilayah Kabupaten Kendari dan KabupetcnKolaka. Karena itu untuk membedakan suku Tolaki yamg mendiami kedua daerah tersebul maka suku Tolaki yang mendiami Daerah Kabupaten Kcndari (bekas daerah kerajaan Konawe) disebut To Konawe, sedangkan suku Tolaki yang mendiami daerah Kabupaten Kolaka (bekas darah lerajaan Mekongga) disebut To Mekongga. Dengan demikian penduduk asli yamg mendiami wilayah kecamatan lambuya adalah To Konawe. Jumlah penduduk mercka diperkirakan mencapai $75 \%$ dari jumlah seluruh penuduk wilayah kecamatan ini.
Penduduk pendatang terdiri dari transmigran umum dan pendatang lain. Transmigran umum berasal dari daerah Jawa Barat, daerah Istimewa Yogyakarta, daerah khusus ibu kota Jakarta raya, dan daerah jawa lainnya.Pendatang yang merasal dari bali duscbut transmigran " sisipan ", dari daerah bugisdi Sulawesi Selatan dan daerah kabupaten lain di Sulawesi tcnggara disebut transmigran " spontan ", pendatang yng berasal dari satuan-satuan ABRI disebut tansmigran satuan atau" transat". penduduk pendatang ini menempati dan bahkan menjadi penduduk mayoritas pada 8 (dclapan) desa di wilayah kecamatan Lambuya, yakni Matahoalu, tawamclcwc. trimulya, Ulu Meraka. Soanai, Basala, Puunggakawu, dan sandarasi Jaya. Jumlah penduduk pendatang diperkirakan mencapai $425 \%$ dari jumlah seluruh penduduk kecamatan.

Penduduk usia produktii menckuni bidang-bidang kegiatan yang menjadi sumberpenghasilan atau mata pencaharian sebagai pctani, pedagang, pengusaha, buruh, pegawai negeri. Bagian tcrbesar penduduk ncbekuni pekcrjaan di bidang pertanian (patani tradisional sawah dan ladang) yakni kira-kira sebanyak93,3\% yang bckcrja sebagai nclayan scbanyak $0,8 \%$, pedagang $0,6 \%$, pcrjin ), $3 \%$, pengusaha ). $1 \%$, buruh industri dan bangunan $0,9 \%$, pegawai negeri sipil dan ABRI $4 \%$ termasuk pensiunan $0,4 \%$.

Penduduk asli baru sekitar satu dasawarsa tcrakhir mcncrapkansislem pcrtanian denga pola menctap dan sistem persawahan. Dalam waktu lama scbelumnya mercka mclkukan perladangan berpindahpindah. Kedatangan transmigran sangat membantu penduduk aski meningkatkan 
sisicm pertanian di samping penularan etos kcrja produktif

\section{Penggolongan dan pelapisan sosial}

Penduduk asli To Konawe mengenal tiga jenjang pelapisan sosial tradisional, yakni: (1) golomgam anakia atau bangsawan. (2) golomgam toono motuo ataupenghulu/pemimpinkomunitas, dan(3) Toomo dadio (rakyat kebanyakan; toono= orang datang).

Dalam kehidupan masyarakal, seliap golongan mcmiliki hak dan kewajiban serta peranan masing-masing. Namun demikian mcrcka (kctiga golongan) merupakan salu kesatuan yang masing-masing saling menunjang satu dengan yang lain. Hal ini tcrccrmin dalam simbol adal mercka yang dikcnal dengar dengan sebutan "kalo sara" bentuk simbol ini tcrdiri dari rotan kccil dililit tiga.arah lilitan dari kiri kekanandan berpilin menjadi satu. Simbol ini melambangkan bahwamasyarakatTolaki dari tiga pelapisan sosial bcrsatu dalam menghadapi masalah bersama atau memutuskan sualu masalah dengan cara bcrmusyawarah.

Alribut pelapisan sosial bagi suku Tolaki biasanya dikaitkan dengan jabatan yang dipangkunya; misalnya dapat dilihal/ dikcnal pada bentuk rumah, jenis dan model serta wamapakaian.Gclar kebangsawanan lidak dikcnal dalam sistcm pelapisan sosial To Konawe, kecuali bagi bangsawan yang mcmcgang jabatan pemcrintahan (kerajaan) atau kepemimpinan sosial; sepcrti gclar raja tcrscbut Makole, gclar penguasa wilayah discbut puu tobu atau pimpinan komunilas disebut toono motuo; gelar-gelar tersebul hanya bcrlaku sclama mcmangku jabatan atau memcgang pimpinan.

Dcwasa ini, gelar-gelarjabatan tcrscbut, tentu saja tidak dijumpai lagi karena telah diganti dengan istilah-istilah baru yang bcrlaku umum dalam sistcm pemcrintahan seperli Bupati Kepala Daerah, Camat, Kepala Desa atau Lurah, Kepala Kampung/ Dusun. Namun demikian dalam proses suksesi kepemimpinan formal pemcrintahan Kecamatan Lambuya sejak bcrlakunya LIndang-undang Nomor 29 Tahun 1959 (undang-undang icntang Pcmbentukan Daerah Olonom Tingkat II di Sulawesi Tenggara). Peranan pelapisan sosial tcrtentu rupanya tetap diperhitungkan. Dari 13 kali pcrganiian Carnal sclama pcriode 1959 sampai 1991. hampir seluruhnya bcrasal dari keiurunan pelapisan sosial pcrtamadan/ atau kedua (golongan anakia dan/a tau toono mottio).

Demikian pula dalam kepemimpinan sosial peranan pelapisan sosial tradisional rupanya ictapdipcrhitungkan, bahkansering mencniukan, terulama dalam hal-hal yang berkaitan dengan adat-istiadat.

Selain karcna laktor keiurunan dan keaslian, terdapat pula pelapisan sosial yang didasarkan pada lakior-laktor senioritas, kekayaan, ilmu dan keahlian,jabatan dalam pemcrintahan, dan perkawinan (mobililas verlikal). Dengan tcrbukanya kescmpatan luas bagi seliap anggota masyarakal untuk mempcroleh dan monikmati pendidikan maka sistcm pelapisan sosial secara bcrangsur didominasi oleh laktor pendidikan dan kcahlian yang dimiliki seliap orang/ anggota masyarakat.

Ill KONFIGURASI DAN TRANSFORMASI KEHIDUPAN AGAMA DI KECAMATAN LAMBUYA

1. Gambaran Umum

Penduduk Kecamatan Lambuya yang berjumlah 34.316 jiwa itu, hampir $90 \%$ 
diantaranya memeluk agama Islam, terutama penduduk asli To Komawe. Lebih $25 \%$ penduduknya adalah para pendatang, baik dalam rangka program transmigrasi maupun pendatang lain. Terdapat 79 buah masjiddanmushalah, tersebarpada3 1 desa, sebagian besar difungsikan untuk melakukan shalat Jum'at disamping shalat fardu lima waktu sccara bcrjamaah. Juga sebagian difungsikan sebagai tcmpat be1 aj ar baca-tul is Al-Qur'an, tern pal pengaj i an umum, Majclis Taklim dan lempat mcmperingati dua hari raya dan hari-hari bersejarah lainnya dalam Islam. Proses sosialisasi agama di kalangan anak-anak secara formal dilakukan pada 51 SD, sebuah Madrasah Ibtidaiyah, 7 SMTP diantaranya sebuah Madrasah Tsanawiyah swasta, dan dua SMTA swasta.

Urusan kemakmuran masjid dan mushalah (dalam arti pemeliharaan fisik dan pengaturan fungsi) dipcrtanggung jawabkan pengurus masjid masing-masing dibawah koordinasi Imam Dcsa yang berjumlah 30 orang (satu desa tidak mcmpunyai Imam Desa karena hanya 4 orang penduduknya beragama Islam yakni Desa Tawamelewe). Sebagian besar Imam Desa tersebut berfungsi pula selaku Pembantu PPN. Scmentara itu proses sosialisasi agama bagi anak-anak yang bclajardi lembaga pendidikan formal dibimbing oleh 53 orang guru agama (Islam) berstatus pegawai negeri (terdiri dari 17 orang "nip lima belas" dan 36 orang "nip tiga bclas") dan 9 orang guru agama sukarela. Mcreka inilah yang berpcran utama melakukan upaya pembinaan dan pclayanan langsung kepentingan kcagamaan masyarakat dalam rangka meningkatkan pemahaman dan pengamalan ajaran Islam bagi pemelukpcmeluknya (transformasi, di tengahtengah kondisi/corak kehidupan sosial kcagamaan masyarakat yang cenderung mengikuti pola kehidupan tradisional (=konfigurasi setting awal), schingga pada gilirannya mclahirkan bentuk dan corak kehidupan beragama masyarakat/umat Islam seperti keadaannya dewasa ini (=konfigurasi transformasi).

\section{Pendidikan Agama}

Di bidang agama, masyarakat pada umumnya cenderung mempcrcayakan sepenuhnya pendidikan agama bagi anakanak mercka kepada guru-guru agama di sckolah. Kalau dahulu, anak-anak belajar mengaji (belajar membaca Al-Qur'an dan belajar pengetahuan dasar dan praktek agama) dilakukan di rumah-rumah guru ngaji tradisional maka dewasa ini orang tua pada umumnya mengharapkan agar pclajaran mengaji juga diintensifkan pelaksanaannya di sckolah-sekolah. Kckurangan jam pclajaran agama di sekolah, dianjurkan oleh orang tua agar guru-guru agama mcnutupi kckurangan itu dengan mcnyclcnggarakan pclajaran agama ekstra kurikulcr (sang guru mendapat semacam imbalan jasa dari orang tua anak) dengan bobot materi lebih dititikberatkan pada pendidikan akhlak dan praktek ibadah. Keinginan orang tua demikian itu ternyata mendapat respons positif dari guru-guru agama yang memang dituntut untuk mengembangkan pclajaran agama ekstra kurikulcr (bcrdasarkan Instruksi Bcrsama Kepala Kanwil Dcpag, Kepala Kanwil Dcpdikbud, dan kepala Dinas $P$ dan K Propinsi Sulawesi Tenggara, April 1991). 


\section{Dakwah/Penerangan Agama}

Di bidang dakwah, harapan dan perhatian masyarakat banyak digantungkan pada aktivitas KUA Kecamatan dan Guruguru agama dalam hal penyediaan da'i/ muballigh secara kontinyu dan bcrkualilas. Kalau dulu masyarakat menganggap aparat syara' (Imam Kampungdan/atau Imam Desa bescrta pembantu-pembanlunya) sebagai figur scntral dakwah Islamiyah maka kini masyarakat lebih mengharapkan adanya da'i/muballigh yang bcrwawasan luas. Dalam hal ini lampaknya aparal KUA dan aparat departemen Agama lainnya masih menjadi andalan masyarakat, walaupun ada pula sementara anggoia masyarakat yang lebih menghendaki da'i/muballigh professional untuk didalangkan sckali-sekali dari luar daerah. Tumpuan harapan masyarakal kepada aparat Departemen Agamademikian besarnya karcna kurangnya anggoia masyarakat non PNS yang mcmiliki kemampuan sebagai da'i/muballigh yang diharapkan masyarakat. Masuknya para pendatang melalui program transmigrasi lebih rriemperkayakonfigurasidan transform asi aktivitas dan pemahaman keagamaan masyarakat, baik kualitas maupun kuanlitas. Dari segi kualitas, banyak pendatang yang dianggap masyarakat sctempat sebagai "muballigh professional" (walaupun dalam ukuran lokal) sementara dari segi kualitas, para pendatang mcmbawa scrta/mcmpcrkenalkan bcragam media dakwah tradisional yang berlaku di daerah asal kemudian dikembangkan di lokasi pemukiman baru dan pada gilirannya diadopsi masyarakal penduduk asli. Antaralain, sistem yasinan, Tadarusan, lahlilan, pembacaan kitab bar/.anji dengan alau tanpa modifikasi, di- laksanakan secara bcrkala dan/atau secara insidentil. Tenia dan materi dakwah yang cendcrung diminali masyarakat secara umum berkisar pada keimanan/lauhid. praktck ibadah, dan pendidikan akhlak.

\section{Lektur Keagamaan}

Pcmilikandanminal bacaleklurkeagamaan di kalangan masyarakat pada umumnya masih rendah. Di rumah-rumah anggoia masyarakat biasa paling banyak dijumpai Kitab Suci Al-Qur'an dalam kondisi fisik lak icrurus, Al-Qur'an kecil "Jus Amma", dan buku-buku pclajaran agama anak-anak sekolah. Di rumah guru-guru agama dan Imam Dcsa/Pcmbanlu PPNdapaidilemukan Icklur keagamaan yang scdikit bcragam dianiaranya ada "kitab gundul" dengan bcrmacam-macam judul. Pada bebcrapa kcluarga pendalang (eks transmigran asal Jawa) dapal dijumpai lektur keagamaan yang lebih lengkap, baik buku-buku yang menggunakan Bahasa Indonesia serta bahasa daerah Jawa dan Sunda (dengan menggunakan lulisan Arab Pcgon) maupun "kilab gundul" alau "kitab kuning" yang mcmuat bahasan berbagai cabang ilmu seperti Ilmu Fiqlii, Usui Fiqhi.Tafsir, Hadits, Tasawwul, Akhlak, Tauhid, dan cabangcabang ilm u alat (pengctahuan bahasa Arab) seperti Nahwu. Sharaf dan Balagah.

Perpustakaan sekolah untuk kcperluan pclajaran siswa tcrmasuk pclajaran agama, i tu pun dalamjum 1 ah dan variasi yang sangal tcrbatas. Harapan masyarakat dalam hal pengadaan lektur keagamaan rupanya banyak dilujukan kepada "kebijaksanaan KUA" dan instansi Departemen Agama lainnya, bahkan bebcrapa orang mengajukan langsung harapan mcreka kepada pcneliti (maksudnya pcneliti dalam rangka peneli- 
tian yang dilaporkan ini). Terutama mengcnai penyediaan Kitab Suci Al-Qur'an scrta buku pedoman belajar ccpat baca tulis Al-Qur'an yang kini sementara hangat dibicarakan di lokasi penelitian sehubungan dengan adanyainstruksibersamatigapimpinan instansi pemcrintah terkait di tingkat Propinsi Sulawesi Tenggara. Kcbutuhan masyarakat setcmpat tcrhadap Kitab Suci Al-Qur'an dan buku pcdoman belajar membaca ccpat Al-Qur'an juga dirangsang olch pelaksanaan sclcksi qari' dan qariah sccara merata kc seluruh pclosok dcsadalam rangka mempersiapkan pcrulusan Propinsi Sulawesi Tenggara mengikuti sclcksi nasional Musabaqah Tilawatil Qur'an yang kcbetulan akan dilaksanakan di Kola Kcndari pada tahun 1992 yang akan datang.

\section{Organisasi dan Kepemimpinan Agama}

Organisasi kcagamaan di lokasi penelitian tampaknya jarang yang beroricntasi kepada organisasi level nasional sepcrti NU, SI, Muhammadiyah, bahkan GUPPI dan MDI jarang dijumpai di desa-desa. Organisasi kcagamaan yang ada mevupakan organisasi lokal yang dibentuk menurut kebutuhan nyatamasyarakat dalam rangka upaya peningkatan pengetahuan dan pengalaman ajaran agama scrta pemberian makna agama di dalam kehidupan seharihari.

Bentuk-bentuk organisasi yang berkembang dalam masyarakat di lokasi penelitian seperti, perkumpulan, pengajian, Majlis Taklim, Yayasan, Lcmbaga Swadaya Masyarakat (LSM) yang beroricntasi kcagamaan, organisasi rcmaja masjid. kepanitiaan, disamping P2A (Pembina dan penyuluh agama) yang dibentuk atas "pesan top down" (dalam hal ini KUA). Organisasi yang bertendensi kebatinandan tarekat tidak dipcrolch informasi tentang adanya di lokasi penelitian. Pcrnah aliran "Islam Jamaah" bcrupaya "menawarkan" diri pada tahun 1990 namun tidak mendapat pasaran sehingga hilang dengan sendirinya dalam pcrcdaran. Di ibukota kecamatan sementara dikembangkan satu kegiatan yang bcrsifat scni bcla diri yang mengandalkan "kckuatan dalam", nama lengkapnya Seni Pembclaan diri (disingkat SPD). Organisasinya berbentuk perkumpulan yang bcrsifat lokal dan lebih mencirikan diri sebagai alal dan mctodc dakwah daripada sebagai satu aliran atau tarekat. Untuk dapat mengikuti/menjadi anggota perkumpulan ini disyaratkan scorang haras taat mclaksanakan ibadah terutama salal lima waktu, bcrakhlak baik, dan syarat-syarat lainnya yang pada umumnya bcrsifat didikan budi pekcrti scsuai dengan akhlak Islam.

Kepemimpinan ulama dan tokoh agama tclap dominan, baik sccara formal (dalam struklur organisasi kcagamaan) maupun sccara informal (da)am masyarakat pada umumnya), kemudian disusul tokoh adat, dan pejabat formal. Soring kepemimpinan adat dan agama mcnyatu dalam diri atau ligurscscorangdan agaknya lipc kepemimpinan ini dianggap ideal olch Masyarakat/umal Islam setcmpat. Bakrin Daranga, Kcpala KUA Kecamatan Lambuya sekarang ini. mencrapkan pcrtimbangan tentang tipc kepemimpinan yang dianggap ideal olch masyarakat setempat, dalam mcmilih/mengusulkanpengangkatan Pcmbantu PPN di setiap Desa. 


\section{Bimbingan dan Pelayanan Agama}

Bimbingan dan pelayanan kehidupan

beragama masyarakat/umat Islam di lokasi penelitian, secara umum masih didominasi oleh aparat Departcmen Agama, baik aparat KUA beserta dengan pembantu-pembantunya di setiap desa (yakni Pembantu PPN) maupun guru-guru agama. Pcrscpsi masyarakat terhadap bidang tugas dan fungsi KUA demikian luasnya sehingga hampir seluruh kcbutuhan pelayanan kepcntingan kcagamaan mercka harapkan dari KUA. KUA tcntu saja tidak mampu mcmenuhi harapan itu karena kcterbatasan yang dimiliki, baik kcwcnangan dan bidang tugas maupun sarana dan fasilitas pcnunjang pelaksanaan tugas. Akibatnya masyarakat/umat Islam mcrasa kurang puas atau pelayanan yang dibcrikan KUA dan menganggap KUA kurang bcrlungsi atau kurang berperan dengan baik.

Scbenarnya KUA setcmpat bersama aparat Departcmen Agama lainnya, sclama ini banyak melakukan kegiatan pelayanan masyarakat di luar tugas pokok dan f'ungsinya, disamping pelaksanaan tugas dan (ungsinyaitusendiri. Baiktugas-tugas unsur Departcmen Agama lainnya, scperti Urusan Haji (bimbingan manasik haji), Pencrangan Agama Islam (pcnyuluhan dan dakwah langsung), Pendidikan Agama Islam (mcmotivasi masyarakat mendirikan madrasah), kerukunan umat beragama turut mcnyclcsaikan masalah dan mengkondisikan adanya pola hubungan yang kondisional; bahkan kegiatan-kegiatan di luar bidang tugas Departcmen Agama, scperti kegiatan lintas scktoral dalam hal/bidang KB, keschatan, pcrianian, pelcstarian lingkungan hidup, dan kegiatan lain dalam rangka mcmasyarakatkan strategi dan program GERSAMATA (Gerakan Dcsa Makmur Mcrata) Sulawesi Tenggara.

\section{KESIMPULAN DAN SARAN}

1. Pelaksanaan Pclajaran Agamabagi anakanak Sckolah secara ekstra kurikuler tampaknya telah menjadi model alternatif yang diinginkan masyarakat setelah memahami kcterbatasan kurikulum yang berlaku. Karena itu pengembangan sistcm belajar agama ekstra kurikuler ini pcrlu dipikirkan dan diupayakan, karena sckaligus dapat merangsang animo dan aklivitas masyarakat untuk menggalakkan pelaksanaan pendidikan agama non/inl'ormal. Diatas semua itu, upaya peninjauan kembali kurikulum scbagai bagian dari upaya perbaikan sistem pendidikan agama mcrupakan kebijaksanaan yang stratcgis.

2. Di bidang dakwah masyarakat pedesaan juga telah mempcrsoalkan kualilas, namun oricntasi isi/materi yang diinginkan be rkisarpadakcimanan, ak hi ak, dan ibadah. Sejalan dengan harapan masyarakat yang sebagian besar terturnpu pada KUA dalam hal pembinaan dan pelayanan kepcntingan kcagamaan mercka maka scyogyanya di setiap KUA ditcmpatkan sekurang-kurangnya scorang pegawai yang prolesional di bidang dakwah atau memiliki polcnsi untuk dapat bcrkembang menjadi dai prolesional.

3. Perhalian masyarakat dalam pengadaan dan minat baca lcktur kcagamaan masih rendah, hal mana didukung oleh lidak tcrsedianya kcpuslakaan umum dan tokotoko buku serta rendahnya daya bcli 
mereka. Untuk itu perlu diupayakan pengadaan lcktur keagamaan yang dapat dijangkau daya beli dan daya serap umat Islam secara umum. Pengadaan perpustakaan masjid perlu mendapat dukungan semua pihak yang merasa bertanggung jawab secara formal dan moral.

4. Pcngorganisasian aktivitas keagamaan di kalangan masyarakat cenderung mengarah kepada pembentukan organisasi lokal yang didasarkan pada kcbuluhan nyata masyarakat dalam rangka upaya peningkatan pengetahuan dan pengamalan ajaran agama. Keccndcrungan ini perlu didorong dan dibina agar lebih cfektif dan tidak menjadi ajang pcrsaingan yang dapat merusak ukhuwwah. Pembentukan organisasi/lembaga semi resmi rekayasa "top-down" di desa-desa perlu mengindahkan aspirasi yang tumbuh dan berkembang dalam masyarakat tcrutama menyangkut tipe kepemimpi- nan yang dianggap ideal oleh masyarakat setempat.

5. KUA (Kantor Urusan Agama) Kecamatan "telanjur" dipersepsikan masyarakat di pedesaan sebagai "miniatur komplit" Departemen Agama. Hampir seluruh kcinginan dan harapan masyarakat kepada pemcrintah menyangkut pembinaan dan pclayanan kchidupan bcragamaditujukan kepadadan/atau mclalui KUA Kecamatan. Schubungan dengan itu perlu peninjauan struktur, tugas, fungsi, dan eselonisasi, serta penyediaan saranadan fasilitaspcndukung,agardapat bcrpcran lebih banyak dan lebih berkualitas dalam rangka upaya mcmcnuhi harapan masyarakat dan tuntutan perkembangan; terutama dalam upaya mcmpcrsiapkan masyarakat umat beragama menyongsong era tinggal landas pembangunan serta mclakukan kegiatan awal era tinggal landas pembangunan ter-sebut. 


\section{DAFTAR KEPUSTAKAAN}

\author{
Abdullah, Taufiq (Ed). \\ 1983 Agama dan PerubahanSosial. \\ Jakarta, Rajawali.
}

Ahmad Syafi'i

1991 Konfigurasi dan Transformasi Kehidupan Agama Menjelang Tinggal Landas Pembangunan Nasional (Tahap Pertama). Rangkuman Penelitian Jakarta, Proyek Penelitian Kcagamaan Badan Litbang Agama.

Chalik, Husen A.

Konawe (Aneka Ragam
Kebudayaan Kabupaten Ken-
dari). Kendari, Stcnsilan,
tanpa tahun

EfTendi, Djohan (Fd).

1980 Agama dan Masa Depan: Sebuah dialog tentang Konfigurasi dan Transformasi Kehidupan Agama di Indonesia, Jakarta, Badan Litbang Agama.
Koentowijoyo

1987 Budaya dan Masyarakat. Yogyakarta, Tiara Wacana.

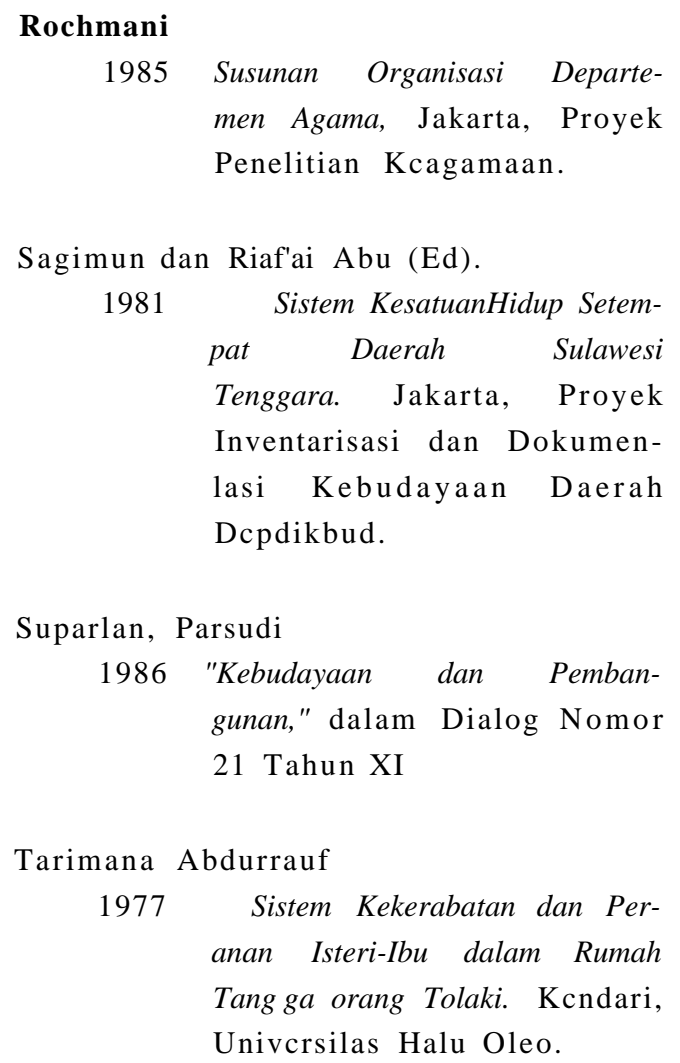

